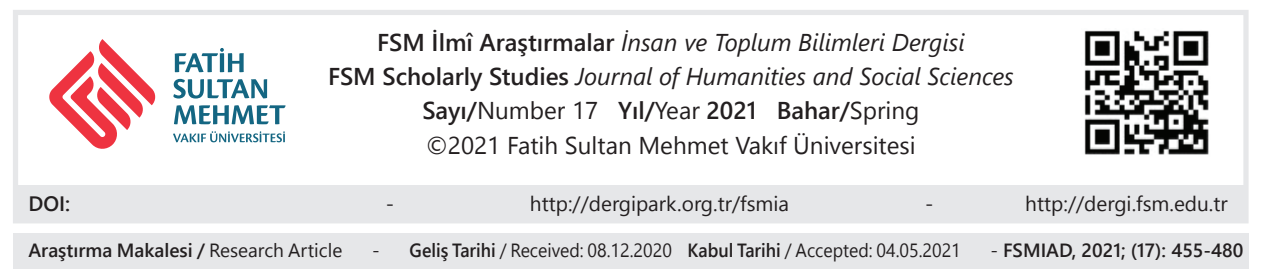

\title{
Fantazmagorik Bir Mekân Olarak Twitter ve Simülatik Flâneurler
}

Murat Bozkurt*

\section{$\ddot{O} z$}

Bu çalışmanın hedefi etkileşimli ve katılımcı bir medya türü olan yeni medyanın politik/ideolojik söylem üretiminde en etkili mecralarından biri olan Twitter'ın yapısını ve kullanıcılarının varoluşsal konumu mekân ve kimlik olguları üzerinden çözümlemektir. Modern yaşamın ontolojik anlamda doğal, teknik anlamda yapay bir uzantısı olan, bir bireyselleşme/toplumsallaşma pratiği olarak sosyal medyanın modern birey üzerindeki varoluşsal boyuttaki etkisi; bireysel ve toplumsal yaşantıdaki duyuş, düşünüş, algılayış ve davranış kalıplarını dönüştürmesi; son olarak tarihteki örneklerinden çok farklı bir insan ve uygarlık türünün oluşumundaki inkâr edilemez rolünün arka planındaki paradigmatik değişim irdelenmektedir. Bu hedeflere ulaşmak amacıyla öncelikle (I) sosyal medyanın modern çağ ve paradigma içindeki yeri ortaya koyulduktan sonra (II) mekân ve kimlik açısından benzeşim kurulan kavramların (fantazmagori, simülasyon ve flâneur) literal ve kuramsal kullanım biçimleri, tanımları, anlam alanları ve Twitter pratiği ile benzerlikleri ilişkilendirilmektedir. Daha sonra (III) Twitter'ın teknik yapısı mevzu bağlamında ele alınmakta, son kısımda ise (IV) dijital bir mekânda inşa edilen dijital kimliklerin oluşturduğu dilin (söylemin) bazı politik/ideolojik/parodik yönleri tespit edilmekte ve fenomen/ flâneur tipi semiyotik açıdan değerlendirilmektedir.

Anahtar Kelimeler: Fantazmagori, simülasyon, flâneur, Twitter, dil, kimlik, söylem.

* Doktora öğrencisi, öğretmen ve yayınevi editörü, İstanbul/Türkiye, tarpizos@gmail.com, orcid.org/0000-0002-3368-4029 


\title{
Twitter as a Phantasmagoric Space and Simulatic Flâneurs
}

\begin{abstract}
This article aims to structurally analyze Twitter as an interactive, participatory media type that is one of the most effective channels of new media in political/ideological discourse-production, as well as the existential position and situation of its users, through the phenomena of space and identity. Given social media as a practice of individualization/ socialization is an ontologically natural, technically artificial extension of modern life, the article explores its existential effects upon the modern individual; its transformation of the emotional, reflexive, perceptive and behavioral patterns in individual and social life; finally the paradigmatic change behind its undeniable role in the formation of a particular type of human being and civilization that are very different from their precedents in history. To do this, primarily (I) the place of social media within the modern age and paradigm will be elaborated, then (II) literal and theoretical uses, definitions, areas of meaning and similarities with the practice of Twitter of concepts (phantasmagory, flaneur and simulation) that are likened to each other in terms of space and identity are examined. The following section (III) contextually introduces the technical structure of Twitter and the final section (IV) detects certain political/ideological/parodical aspects of the language (discourse) constituted by digital identities in a digital space and reassesses the phenomenon/flâneur type semiotically.
\end{abstract}

Keywords: Phantasmagoria, simulation, flâneur, Twitter, language, identity, discourse. 


\section{Giriş: Sosyal Medyanın Modern Çağ ve Paradigma İçerisindeki Yeri}

"Enformasyon çağı" olarak nitelendirilen günümüz dünyasının en belirgin özelliklerinden biri, onda sadece kitle iletişim araçlarının aktif ve yaygın olarak kullanılması değil, aynı zamanda bu medyalar (araçlar) aracılığıyla "sanal ve hayali cemaatler" oluşturulmasıdır. Kimi zaman bir marka cemaati, kimi zaman bir fan grubu, kimi zaman lokal bir dernek, kimi zaman toplumsal bir sinif dayanışması, kimi zaman politik ve ideolojik örgütlenmeler, kimi zaman ekonomik yapılanmalar olarak karşımıza çıkan, benzerleriyle ve karşıtlarıyla bir ağ ören "hayali cemaatler", hızlı, yaygın ve etkili bir haberleşme/dayanışma içinde olabilmek amacıyla internetin "akışkan" zeminini kullanarak "sanal cemaatler" hâline dönüşmeye başlamışlardır. Forumlar, fan sayfaları, sözlükler, bloglar, Facebook toplulukları, WhatsApp grupları, arkadaşlık aplikasyonları, mail grupları, kitlesel mesajlaşma uygulamaları, Twitter klikleri vb. şeklinde tezahür eden içsel ve iletişimsel bağlar ile çağdaş bireyin/toplumun sarı sarmalanması ve kitlesel biçimde yapılandırılması aslında insanlık tarihinin başlangıcından bu yana var olan ă̆ toplumunun bağlamının ve bağlarının değiştiğini göstermektedir.

Sosyal bir varlık olan insanın bireysel ve toplumsal kimliğini (ki kimlik bireysel olmaktan çok toplumsallaşma süreciyle ilişkilidir) inşa edebilmek adına kendisini aidiyet ve mensubiyet bağıyla bir şekilde bir aileye, gruba, sınıfa, cemaate, etnisiteye bağlaması, gerçek hayat düzleminde de devam etmekle birlikte artık sanal ve simülatik bir düzlemde de kendini bir "ihtiyaç" olarak dayatmaktadır. Sanal bir aidiyet/mensubiyet ilişkisiyle vücut bulan bu muhtaçlık hâli öznenin (insan/topluluk) ve nesnenin (eşya/alet/medya) karşılıklı biçimlenişine sebep olmaktadır. Castells' in deyişiyle "interaktif bilgisayar ağları, yeni iletişim biçimleri ve kanalları yaratarak, hayatı şekillendirerek ve aynı zamanda hayat tarafindan şekillendirilip katlanarak büyüyor." Sosyalliğini ve sosyal kimliğini sosyal ağlar üzerinden (veya asosyalliğini sosyal ağlar üzerinden yahut sosyalliğini asosyal ağlar üzerinden) kurmaya çalışan çağdaş birey ve toplum, McLuhan'ın teknolojik determinist ifadesinden mülhem, biçimlendirdiği araç (medya) tarafindan biçimlendirilmektedir. ${ }^{2}$

Kaynak olarak esasen birer "elektronik devrim" olan bütün çağdaş devrimler hayatımızı fazlasıyla "akışkan" ve hızlı, dolayısıyla yüksek gerilimli hâle getirmiştir. Elektroniğin büyüsünün Pandora'nın kutusunu açtığ 1 aşikârdır. "Teknolojik Prometheuslar", yarattıkları android bireylerin bilinçaltını kışkırtıp kötücül tabi-

1 Manuel Castells, Enformasyon Çağl: Ekonomi, Toplum ve Kültür: Ăg Toplumun Yükselişi, İstanbul, İstanbul Bilgi Üniversitesi Yayınları, 2013, s. 3.

2 Bkz. Marshal McLuhan, Yaradanımız Medya, İstanbul, Nora Kitap, 2019. 
atını elektrik akımıyla canlandırmıştır. Kötülüğün (bayağılığın ve banalliğin) sâri bir hastalık/veba gibi yayıldığı çağdaş toplumun organizması, elektriğin şokuyla bedeni diri ama iç organları iflas etmiş bir Frankenstein gibidir. Kurmacadaki Dr. Frankenstein'ın bilimsel kibri ve Tanrı'nın yerine geçme arzusu (benzer bir diğer kurmaca karakter Faustus'tur) gibi “Teknolojik Prometheuslar" ve modern insan da geleneksel hayat tasavvurunda merkezî bir konumda bulunan Tanrı'nın kovulduğu yeri işgal etme çabasındadırlar. Protagoras'tan bu yana her şeyin ölçütü ve ölçüsü hâline getirilen insanın, görünür görünmez (fizik-metafizik) ağlarla ilişkili olduğu "göksel" boyutla bağlarının kop(arıl)ması, insanın âdeta gökten yere (seküler düzleme) çakılmasına sebep olmuştur. Yatay ve dikey boyutlar arasında tek taraflı biçimde (birey tarafindan kesilerek) gerçekleşen kopukluk, insanı profan bir paradigmaya, hayat algısına, yaşam biçimine sarılmaya itmiş veya tam tersine söz konusu paradigma değişimi onun yere çakılmasını neticelendirmiştir.

Söz konusu profan/seküler hayat algısı ve yaşam biçimi insanın varoluşsal korkularını hortlatmıştır. Bu korkuların başında yokluk/ölüm düşüncesi gelmektedir. Dünya Savaşları gibi tecrübeler Batılı modern insanı ontolojik açıdan oldukça sarsmıştır. Kant’tan mülhem Heidegger'in “ontolojik güvensizlik” dediği durum modern insanın kendine "epistemolojik güvenlik alanları" inşa etmesine ${ }^{3}$, daha basit bir söyleyişle dünyaya ve dünyeviliğe (hazza, hıza, maddeye, eşyaya) sarılmasına yol açmıştır. Varoluşsal korkularından korunmak için ("korumak" sözcügü ile "korkmak" sözcüğü arasında etimolojik bir akrabalık vardır) bilişsel/ bilgisel alanlar açan ve bu alanlar arasındaki ilişkiyi/iletişimi dijital ağ sistemi üzerinden hızlı bir şekilde kuran modern Batı medeniyeti, kendisine benzemediği için tanımlayamadığı, tanımlayamadığı için bilmediği, bilmediği için korktuğu, korktuğu için de yok etmeye/sömürmeye çalıştığ 1 farklı tüm kültürel havzaları ya denetlemeye ve sömürgeleştirmeye, ya asimile etmeye, yahut da tasfiye etmeye çalışmaktadır. Günümüz medya çalışmaları sosyal medyadan TV ve sinemaya kadar toplumları biçimlendirme ve yönlendirme politikalarının üreticisi ve taşıyıcısıdır. ${ }^{4}$ Kapitalist modern paradigma, ürettiği hâkim kültürel/siyasal/politik kodlar ve bu kodları ileten (yine kendi ürettiği) medyalar aracılığıyla sıkı bir ağ yapılanması kurmuş ve ç/ağdaş toplumu, kalbi/inancı hariç, bütünüyle bağlamış durumdadir.

Castells'e göre, "toplumlarımız ağ ile benlik arasında çift kutuplu bir karşıtlık etrafında yapılan[maktadır]". 5 Silikon Vadisi'nde üretilen yapay cennetin

3 Yusuf Kaplan, "Dijital Medya ve Özgürlük Problemi”, TRT Akademi, cilt 1, 2016, s. 658-680.

4 Bkz. Pierre Bourdieu, Televizyon Üzerine, İstanbul, Yapı Kredi Yayınları, 1997.

5 Castells, a.g.e., s. 4. 
altyapıs1 (makyaj1/dekoru) döküldüğünde söz konusu vadinin aslında Hannem Vadisi (Go-Hannem/Cehennem) olduğu ortaya çıkacaktır. Ama şimdilik bu dijital "ağlar, toplumumuzun sinir sistemi hâline gelmiş" durumdadır. ${ }^{6} \mathrm{Bu}$ "bağımlılık" doğal ekolojiyi olduğu gibi sosyal ekolojiyi (ve ideolojiyi) de çökertmeye matuf görünmektedir. Sanayi Devrimi ve sonrasındaki süreçte gerçekleşen birçok devrimin geleneksel Doğu toplumlarında değil de yeni dünya düzeninin yeni aktörü olan Amerika'da ortaya çıkması ve Doğu toplumlarında birçok bilimsel keşif yapılmış olmasına rağmen "sanayi devriminin kıyısından dönülmüş" olunması Doğu toplumlarının beceriksizliğiyle değil insan ve hayat tasavvurlarıyla açıklanabilir. Needham, "Çin kültürünün hızlı teknolojik değişimlerle baltalanabilecek bir şey olan insan ile doğa arasındaki uyuma, Batı'nın değer yargılarına kıyasla daha fazla önem verdiğini" ifade etmektedir. İnsanı ve doğayı ele geçirilecek birer nesne olarak gören modern Batı düşüncesinin pratik alandaki en büyük uygulayıcısı olan ABD'nin teknolojik ilerlemenin döl yatağı olması ve bu alandaki birçok keşfin militarist çalışmalar sonucu ortaya çıkması teknolojinin arka planındaki sosyal ve siyasal itkiyi ele vermektedir. Konumuzla doğrudan ilgili olan ve dijital ağ toplumunun varlık zemini sayllabilecek internetin doğumunun ABD Savunma Bakanlığı İleri Araştırmalar Kurumu'ndaki savunma ve casusluk araştırmaları sonucu gerçekleşmiş olması bu yargımızı pekiştirici niteliktedir. ${ }^{8}$ Yine "küresel ve yatay iletişimin" temeli olan internetin modern ağ toplumunun varlık sahası oluşu ve bu sahanın ABD gibi yeni dünya düzeninin kurucu aktörünün eliyle inşa edilmiş olması bu sahanın "özgürlükçü/demokratik/liberal/hümanist" bir düzlem olduğu hususunda elbette sağlam şüpheler doğuracaktır.

Elektroniğin akışkan yapısının dijital ağ toplumlarının hızlı oluşumunu ve yayılışını biçimsel olarak da içeriksel olarak da etkilediği söylenebilir. A $\breve{g}$, yapı itibariyle dikey ve yatay bağların kesişmesiyle meydana gelen boyutsuz ve yüzeysel -organik ve mekanik; teknolojik ve enformatik; ideolojik ve politik- fraktallerden oluşan bir sistemdir. Birbirini tekrar eden bu "arabesk" form boyutsuz olmasına rağmen bir derinlik hissi vermektedir. Castells'in sade tanımlamasıyla “ağ, birbiriyle bağlantılı düğümler dizisidir. Düğüm ise, bir büklümün kendini kestiği noktadır." ${ }^{\circ}$ Düğüm ağın hücresini (yani biyolojik yapısını); büklüm ağın uzvunu (yani fiziksel sınırlarını); düğümlerin büklümlü dizisi de ağın vücudunu (toplumsal ve konvansiyonel mevcudiyetini) oluşturmaktadır.

6 Jan Van Dijk, Ağ Toplumu, İstanbul, Kafka/Epsilon Yayıncılık, 2016, s. 13.

7 Castells, a.g.e., s. 8.

8 Bkz. Herbert Dreyfus, İnternet Üzerine, İstanbul, Küre Yayınları, 2016.

9 Castells, a.g.e., s. 622. 
Biz bu makalede, kültürel şebekenin düğümlerinden/bağlarından biri olan medyanın (bir araç olarak değil, bir olgu olarak medyanın) ve Twitter özelinde sosyal medyanın, Walter Benjamin'in Phantasmagoria ve Flâneur ve Jean Baudrillard'ın Simulation/Simulacrum/Simulacre kavramlarıyla bağ kurarak eleştirel bir değerlendirmesini yapmaya çalışacağız. Enformasyon Çağı'nın kültürel aurasının kökenlerinde yer alan yeni medyanın düğümlerinden biri ve en popüleri olarak beliren Twitter'ın, ağ toplumunun inşasındaki işlevselliğinden çok ağ toplumu içinde bireysel kimlik inşasındaki rolünü irdeleyeceğimiz bu metinde söylem ve içerik analizi ile birlikte (metinler-arası) çoklu okuma yöntemini kullanacağız. Sorumuz değil ama sorunsalımız, aldatıcı bir görüntü/hayali bir zemin (fantazmagori) olarak Twitter'ın politik/ideolojik/parodik/simülatik kimliklerin üremesinde ve bu kimliklerin söylemlerini şekillendirmesindeki etkisidir. Her metin/text ("tekstil" sözcüğü ile aynı kökten gelen text; "örmek", "dokumak" gibi kök anlamlarına sahiptir) kavramlar ve kelimeler, olgular ve olaylar, duy(g) ular ve düşünceler arasında bir "ağ örme" faaliyetidir. Yazmakta olduğumuz bu metin gibi, sınırlı bir karakter hacmine sahip olmasına rağmen bir "hiper-metin" olan Twitter metinlerinin kendi düğüm ve bük(l)ümlü yapısı içerisinde ördüğü ağın, ağ teorisiyle kısmi bir yapısal ve varoluşsal benzerliği söz konusudur. $\mathrm{Bu}$ bağlamda, iletişimin sadece yazılı değil, görsel, işitsel ve interaktif (etkileşimli) bir şekilde kullanılabildiği ağ teknolojisinin bir parçası olan Twitter gibi sosyal ağların gücünü Dijk şöyle ifade etmektedir:

"Dijital kod kullanımının belki de en önemli etkisi metin, görüntü, ses, görsel-işitsel programlar gibi enformasyon ve iletişimin büyük birimlerinin geleneksel/doğrusal dizimlerinin yıkılarak okuyucu, seyredici veya dinleyicinin algılayacağı ve üzerinde istediği gibi işlem yapabileceği hiper-bağlantılara dönüşmüş olmasıdır."10

Akışkan bir zemin olan Twitter'ın ayartıcı ve dönüştürücü doğasını irdelemeye çalıştığımız bu makalede sosyal ağların (sanal/ikincil bir) kimlik ve söylem üretimine etkisini, sosyolojik yapısını Benjamin ve Baudrillard'ın kavramsallaştırdığı olgularla benzetmeler kurarak ve Twitter özelinde ise söz konusu platformun dilini ve "fenomen" olarak nitelendirilen kullanıcıların kimlik ve söylem inşa faaliyetlerini yorumlamaya çalışacağız.

\section{Kavramsal Çerçeve: Fantazmagori, Flâneur ve Simülasyon}

Bu çalışmanın belki de en özgün katkısı bizzat başlıkta özünü izhar ettiğimiz kavramsal giydirmeler/benzetmelerdir. Bunlar birçok sacayağı/arka planı olan 
modernliğe ait olan medyatik bir olguyu sosyo-politik bir okumaya tabi tutmaya kapı aralamaktadır. Başlıkta geçen ve Twitter'ın medyatik tarafından ziyade sosyo-politik tarafinı (aslında medyatik olanla politik olan kesinlikle ayrılamaz) aydınlatmaya yönelik kavramlar; modernlik eleştirileriyle ön plana çıkan Frankfurt Okulu'nun "hariçten gazelcisi" sanat ve gündelik hayat üzerinden imajinatif okumalar yapan Benjamin'in fantazmagori ve flâneur kavramları; diğeri "postmodernliğin başrahibi" olarak adlandırılmasına rağmen postmodernliği ne bir olgu olarak ne de kavram olarak kabul etmeyen, gerçeği kendi istediği gibi üreten modern Batı uygarlığının gerçeği sanallaştırarak varoluşsal zemini kaydırdığını dile getiren ve Nietzsche'den sonra modern zamanların ikinci "çöl(leşme) habercisi” Baudrillard'ın simülasyon/hiper-gerçeklik kavramıdır.

Benjamin "aldatıcı görüntü" anlamına gelen fantazmagori kavramını bir 1st1lah/terim olarak Pasajlar adlı kitabında, modernlikle birlikte değişen ekonomik ve toplumsal hayatın merkezinde yer almaya başlayan fuarın halefi, AVM'nin selefi sayılabilecek "pasaj" denilen mekânın oluşturduğu psiko-sosyo-kültürel aurayı tanımlamak için kullanmaktadır. 19. yüzyıldan sonra erken modernlikle birlikte ekonomik ve toplumsal hayatın merkezinde yer alan pasaj, varoluşsal zeminini yitirmiş modern insanın kendini aldattığ1/oyaladığı/eğlediği ("eğlemek" ile "eğlence" sözcüklerinin kökensel birlikteliği gözden kaçırılmamalıdır) bir varlık alanı işlevi görmektedir. Modanın, metaın, alış-veriş-eğlencenin (yani hâlâ organik özelliğini yitirmemiş bir iletişimin) mekânı olan pasajlar, modern insanın "zaman geçirmek için içine daldığı bir fantazmagori oluşturur. Eğlence endüstrisi de insanı, malın eriştiği düzeye yükselterek, bu fantazmagoriye girmesini kolaylaştırır." ${ }^{11}$ Panayır ve fuar gibi dış mekânlardan farklı bir yapıya sahip olan pasaj daha korunaklı/steril bir iç-mekândır ve bu özelliğiyle, aileden/toplumdan kopmaya yüz tutmuş, başka bir deyişle kendine ve topluma yabancılaşma temayülü gösteren modern insanın sığındığı bir limandır- bu "sığınak" zamanla hayali ve gerçek dünyanın merkezini kaplayacak bir "tapınak" olacaktır. Yar1-kamusal alanlar olan fantazmagorik pasajlar, yar1-bireysel alanlar olmalarıyla da ziyaretçilerini toplumsal ve ailevi sorumluluktan kurtaran ara alanlardır ve onların "günün insanı için nasıl mabedler hâline geldiğini, gündelik yaşamdaki yerlerinin aslında neyi temsil ettiğini” etraflıca düşünmek gerekmektedir. ${ }^{12}$ Kamusal ve özel bir kitle alanı (hibrit alan) açan ve insanı kalabalık içinde gizlenmeye davet eden somut bir mekân olarak pasajın, bir toplumsal hayal ürünü, bir fantazmagori olarak düşünce ve yaşama biçimini şekillendirmesi; sa-

11 Walter Benjamin,. Pasajlar, İstanbul, Yapı Kredi Yayınları, 1993, s. 83-84.

12 Serpil Kırel, Kültürel Çalışmalar ve Sinema, İstanbul, Kırmızı Kedi Yayınları, 2010, s. 280. 
nat, ticaret ve hayatı bünyesinde mezcetmesi; ideolojinin ve politikanın/devletin/erkin bu potansiyel imkânın farkında olarak bu mekânı, yani fantazmagorik bir mekân olan pasajı sistemin ideolojik aygıtına dönüştürmesi (Benjamin buna "kapitalist kültürün fantazmagorisi" demektedir); kısacası sosyo-ekonomi-politiğin inşa ettiği bir mekân olan fantazmagorik pasaj ile sermayenin/kapitalin inşa ettiği; ve dolayısıyla da onun güdümünde yol alan medyanın yapısal ve işlevsel benzerliğini kavramsal olarak birbiri üstüne giydirebilir; ve bunu "siber uzam/ pazar-yeri” tabiriyle pekiştirebiliriz.

Söz konusu olan, malın tutulduğu, bireyin yutulduğu, toplumun uyutulduğu birer "gerçek" mekân olan pasajların fantazmagorik bir toplumsal kurmacaya (aldatıcı bir görüntüye) dönüşmesi ile "Amerikan ürünlerinin temel taşıyıcısı olan ticari yönelimli medyanın" yapısal ve işlevsel benzerliğidir. Her ne kadar biz Twitter'in mekân değil zaman olgusu üzerinden ontolojik olarak değerlendirilmesi kanaatinde olsak da konumuz özelinde bir yeni medya türü/aracı olarak Twitter'ın, ekonomik anlamda pasajlar kadar işlevsel olmasa da politik ve ideolojik anlamda çok daha ileri düzeyde fantazmagorik bir mekân olduğunu söyleyebiliriz- elbette bu durum kullanıldığı siyasi/coğrafi şartlara göre değişkenlik göstermektedir.

Benjamin'in fantazmagori kavramının tamamlayıcısı olan flâneur (dişil hâli flâneuse), mekânı anlamlı kılan insanı karşılamaktadır. Bir Arap deyimine göre mekân orada duran insanla kıymetlenir (şerif'ul mekân b'il-mekin). Fransızca "avare gezinen" anlamına gelen flâneur kelimesi Benjamin'in 1stılahına göre "gezinirken çevre izlenimleriyle düşünce üreten kişi”" manasındadır. ${ }^{13}$ İlkin Fransız şair Baudelaire'ın kullandığı bu kelime, Türk şiirinde Orhan Veli'nin veya hikâyede Sait Faik'in aylak adamına denk düşer. Söz konusu aylak/avare tipleme, "kendini geldiği sınıfın değil kalabalığın içinde, yani büyük şehirde evinde hisseden."14 "yersiz/yurtsuz" bir tiplemedir. Dışarı ile içerinin (toplumsal ve bireyselin; ekonomi ve ideolojinin; meta ve eşyanın; hayat ve gerçeğin; sanat ve ticaretin) mezc olduğu fantazmagorik ve steril mekânları, yani klasik-modern bağlamda pasajları, geç-modern bağlamda AVM'leri, postmodern bağlamda siber-uzam1, yani yeni medya türlerini kendine yurt edinen mezkur tip (karakter değil tip, stereotip), kitle içinde kendini perdeleyen, perdenin arkasında yapay olarak var olan, konumuz bağlamında anonim hesapların arkasında kendisine sanal ve ikincil bir kimlik inşa eden hiper-gerçek varlıklardır. Benjamin'in müspet anlamda kullandığı, Batı düşüncesinin temelinde var olan doğa ile kültür tasnifinde

13 Benjamin, a.g.e., s. 81.

14 Kirel, a.g.e., s. 283. 
hem doğayı (çevreyi) hem kültürü (kenti) tecrübe eden, duyumsayan, birleştiren, buradan hareketle bir yaşam ve düşünce tarzı üreten flâneur tiplemesi, "modern insan"ın prototipidir. Fakat bizim daha çok "aylaklığı", "gezinmesi” ve "yorumlaması" ile benzerlik kurmaya, ilişkilendirmeye çalıştığımız flâneur ile fenomen/ troll tipler/hesaplar, belli bir ideolojinin sözcülügünü yapan üretilmiş tipler olmaklığıyla öne çıkan menfi kişilerdir. Tıpkı flâneur gibi, internet âleminde ve sosyal medyada (özellikle de "doxamatik" bir araç ve ortam olan Twitter'da) aylakça gezinip, gündeme dair haber, bilgi, kanı, toplayıp bunları belli bir bakış açısı (yani politik bir perspektif) dahilinde yoğurup yorumlayarak söylem ve düşünce üreten fenomen/troll tipler sosyal medya kitlesini stabilize ve mobilize edebilen ideolojik karakterlerdir. Bu iki tip (flâneur ve fenomen/troll) arasındaki eylem/biçim benzerliği kitabi değil mecazidir ve modern insan ile postmodern insan arasında dokusal bir bağ örmemizi sağlayacak türdendir. Tüketim toplumunun gözlemcisi olan flâneur ile tüketim kültürünün bizzat üreticisi/taşıyıcısı olan fenomen/troll arasında amaç benzerliği olduğu söylenemez ama yöntemlerinin benzeştiği aşikârdır. ${ }^{15}$

Bütün varoluşsal ve toplumsal sorumluluklardan sıyrılmış modern bir varlık olarak dijital flâneur, fantazmagorik mekânları mesken edinmiş, gerçek ile kurgu arasındaki farkın silindiği hiper-gerçek kişidir. Enformasyonu doxaya dönüştüren, doxa ile dezenformasyon ve misenformasyon sağlayan ve böylece gerçeği üretilmiş gerçekliğe çeviren hiper-gerçek medyanın hiper-gerçek kahramanı (içerik üreticisi) olan dijital flâneur (fenomen/troll), medyanın fantazmagorik yapısını pekiştirmektedir. "Gösteri toplumu"nun etkin bir üyesi olan dijital flâneur toplumun ve toplumsal gerçekliğin nabzını sosyal medyada ölçüp tepkisini/ katkısını sunarak kendi toplumsal varlığını ortaya koymaktadır. Twitter'da, sanal ve ikincil kimlikleri kuşanan medya kullanıcısı/alımlayıcı, tıpkı gerçek hayatta bir karşılığı olan ve kalabalığın içinde kendini saklayan flâneurler gibi -avatarların, parodik veya politik profillerin arkasında gizlenerek, mekânın/medyanın bütün kaçış imkânlarını kullanan örtük/gizli procumerlarıdır. ${ }^{16}$ Kâh bir ideolojinin, kâh bir politik tercihin, kâh popüler kültürün satıcısı ve alıcıları. Gerçek kimliğini gizleyerek varoluşsal ve toplumsal sorumluluklarından sıyrılan (yahut varoluşsal ve toplumsal görevleri bu şekilde gerçekleştirerek doyum sağlayan) muhtelif tiplerin kol gezdiği, konumuz özelinde gerek gerçek hesaplarıyla gerek anonim hesaplarla birçok entelektüelin cirit attığı fantazmagorik mekânlardaki

15 Bu benzerliğe dair bkz. Ed. Filiz Aydoğan, Yeni Medya Kuramları, İstanbul, 2017.

16 Procumer: Türkçeye "üretüketici” olarak çevrilen kelime producer(üretici)+consumer(tüketici) kelimelerinin birleşiminden oluşturulan bir kavramdir. 
pragmatist amaçları Benjamin flâneur tipleme üzerinden şöyle dile getirmektedir: "Flâneur' ün kişiliğinde aydın pazara çıkmıştır. Niyetinin pazarı görmek olduğunu söylese de aslında niyeti kendine alıcı bulmaktır." ${ }^{17}$ Gezinirken çevre izlenimleriyle düşünce üreten bir tip olarak tanımladığı flâneur'ü bir "aydın" olarak gören Benjamin, entelektüelin pazarla tanıştı̆̆ bu geçiş döneminde ekonomik ve politik işlevinin henüz belirsiz olduğunu ifade eder. ${ }^{18}$ Dijital flâneur ise sanal toplumsal pazarın bir influencerıdır; takipçilerini söylemsel ve eylemsel açıdan etkiler, yönlendirir.

İç mekâna ait fantazmagorilerin yanılsamalarıla yanıl(t)arak vakit geçiren, ikincil kimlikler inşa eden, politik ve ideolojik eylemlerde bulunan, popüler kültürün üretim sürecine dahil olan ve taşıyıcılığını yapan, konformist tarzda ekonomik çarkı ilerler hâlde tutan, sanatsal aktivitelerde bulunarak "cemaatleşme" refleksleri sergileyen klasik anlamdaki flâneurlerin siber-uzam içinde hiper-gerçek fantazmagorik alanlar inşa eden postmodern flâneurlere dönüşünü kavrayabilmek için zamanın ruhunu/Zeitgeist'ı ifşa eden Baudrillard'ın “simülasyon" kavramını açıklamak gerekir. Katolik kilisesinin sapkın olarak tanımladığı, gücün tanrısal değil şeytani olduğunu ve onun karşısında sevgiyi (Mesihyen sevgiyi) öne çıkaran, İsa'y1 "Oğul" değil peygamber olarak niteleyen, ruhbanllğı kabul etmeyen, Roma'nın Amor'u (Amor, Roma'nın tersten yazılışıdır, aşk/sevgi anlamındadır ve gücün karşıtıdır) yok etmeye çalıştığını söyleyen ve komünal bir hayat yaşayan Katharcılardan biri olan Baudrillard'a göre;

"Gerçekten sanala kaçarak hayattan kopan, başka dünyalarda kendi hayatını arayan ve TV'yi [en genel anlamda medyayı] bu kaçışın en önemli teknolojik aygıtı gören, hayattan korkan ve kaçanların kendilerini koruyan yanılsamalar (illusion) kurduklarını ve bunlara "gerçek" adını verdiklerini, gerçekten daha gerçek olan "hiper-gerçekliği" ürettiklerini iddia eder."19

Temel kavramımız olan hiper-gerçeği simülasyon ile eşanlamlı kullanan Baudrillard, gerçeğin teknoloji aracılığıyla (ki kendisi dijital teknolojiyi görmüş olsa da onun türevi olan yeni medyanın oluşturmuş olduğu dijital-toplum[sallaşmay1] görmemiştir) sanal hâle getirildiğini, bunun ideolojik ve politik bir sürecin ürünü olduğunu, giriş kısmında bahsettiğimiz "ontolojik güvensizliğin" modern toplumu "epistemolojik güvenlik alanları" inşa etmeye yönlendirdiğini dile getirmiştir.

17 Benjamin, a.g.e., s. 99.

18 Benjamin, a.g.e., s. 99.

19 Ahmet Dağ, Ölümcül Şiddet: Baudrillard'ın Düşüncesi, İstanbul, Külliyat Yayınları, 2011, s. 86. 
Kökü itibariyle Latince "simulācrum/simulō" kelimesinden türeyen (çoğulu "simulācra") simülasyon Baudrillard'a göre, "Bir köken ya da gerçeklikten yoksun olan, gerçeğin modeller aracılığıyla türetilmesine, gerçekten ve fiili olarak var olan bir şeyi veya durumu bütün bileşenleriyle birlikte gerçekleşmiş ve fiilen varmış gibi gösterme durumudur." ${ }^{20}$ Twitter özelinde, gerçekliği olmayan bir sanal karakterin (parody account, bot/anonim/fenomen hesap vb.) bir olay1, görsel/işitsel/yazınsal bir şekilde çarpıtmasına birçok örnek bulunabilir. Sentetik bir gerçeklik algısı (yani post-gerçek) oluşturmanın basit olduğu simülatik bir ortamda kitlelerin politik ve ideolojik olarak dezenformasyonla duyuşsal ve düşünsel bağlamda tahrik edilip harekete geçirilebildiği (örn. "Arap Baharı” olayları) bir dönemdeyiz. "Günümüzde iletişim sistemlerinden müteşekkil matriksin içine hapsolmuş görünen gerçeklik ve algısının atomizasyonu, mobilizasyonu ve transformasyonu... algı biçimlerinin standardizasyonu" konusunda temel güç olan medyanın ideolojik bir aygıt olmaması imkânsızdır. ${ }^{21}$ Simülasyon, Baudrillard'ın da ifade ettiği gibi teknoloji zemininde kurulan toplumsal, kültürel, siyasal, ekonomik vb. bütün alanları kapsar. Batı'nın inşa ettiği ve kapitalizmin güdümünde ilerleyen söz konusu simülasyon evreninde gerçek de varlık da metamorfoz ve her şey "tele-gerçek/tele-varlık" diyebileceğimiz bir hâl almıştır. Hümanizmin merkeze koyduğu "insancılık" (insancıllık değil, insancılık, yani anthropocentricism), yerini makine efsanesinin ürettiği araç/medyaya (ve medyanın ürettiği dijital evrene) bırakmış, anthropo-centric zihniyetin yerini android-centric bir sayısal zihniyet almış gibidir. Kitle iletişim araçlarıyla sâri hâle gelen bu paradigma dönüşümünün (metamorfozunun) temelinde (Tanrısal) bir merkeze sahip olamamak ve dolayısıyla da "ontolojik güvensizlik" duyulması; yüzeyinde ise politika ve ideolojiyi belirleyen sermayenin çarkını çevirme isteğiyle ürettiği "epistemolojik güvenlik alanları" inşa etme gayreti vardır. Enformatik bombardıman altında payına düşen hızı ve hazzı almaya çalışan modern insanın sanal gerçeklik içinde kendisine bir varlık alanı açmaya ihtiyaç duyduğu, aksi takdirde yok hükmünde sayılacağı zannı hakimdir medyalar çağında. Yeni medya (veya sosyal medya) toplumdan, aileden, hatta kendisinden kopmuş, kendisine yabancılaşmış, iletişimsizlik kabzı yaşayan a-sosyal modern insanı e-sosyal bir kullanıcıya/alımlayıcıya dönüştürerek, temel insani bir ihtiyaca cevap vermektedir. Bir sanal iletişim ağı ören postmodern çağ, çeşitli aplikasyonlarla "tele-evren" içinde "tele-varlık" diyebileceğimiz simülatik insanlar meydana getirmiştir. Twitter ile politik/ideolojik, Facebook ile sosyolojik/domestik, Instagram ile ikonik ihtiyaçlarını karşılayan ve böylece toplumsal kimliklerini inşa eden/pekiştiren modern

20 Jean Baudrillard, Simülakrlar ve Simülasyon, İstanbul, Doğu Batı Yayınları, 2003, s. 15.

21 Recep Şentürk, İletişim ve Televizyon Teorileri, İstanbul, Küre Yayınları, 2017, s. 1. 
insanlar, seyredilmekten hazzalan kadın doğası ile seyretmekten/dikizlemekten (voyeurism) hazzalan erkek doğasın $1^{22}$ sanal ikincil kimliklerinde birleştiren cinsiyetsiz (unisex) bir hibrite benzemektedir. İkonanın ağır bastığı Instagram, fantazmanın ağır bastığı Facebook ve doksanın ağır bastığı Twitter gibi uygulamaların iletişim açısından en büyük güçleri audio-visual-verbal (işitsel-görsel-sözel) bütün alg1 türlerini bünyelerinde toplayabilme ve bu üç algı türünden inşa edilen mesajı hızlı ve interaktif (yani "tele") bir şekilde yayabilme özelliğine sahip olmalarıdır.

Konumuz özelinde Twitter, siber uzamda (sanal dünyada, sanal pazarda veya internet sarmalında) oluşturulan fantazmagorik bir söylem alanı işlevi görmektedir. Yazının bile inorganik (ve indirekt) bir mesaj/iletişim biçimi olduğuna inanan kadim kültürlerin ${ }^{23}$ söz ve eylem merkezli yaşam biçimlerinden; görselliğin tahakkümü altında ikonik (bir nevi "modern putperestliğin") bir yaşama biçimine dönüşte ara bir form olan yazının (yazı, dolaylı bir konuşma biçimidir) sanal karakter (sanal söylem ve sanal eylem) inşasında kullanılan Twitter gibi platformların (280 ile sınırlanan karakter sayısındaki karakterin "oymak, metale kazımak" kök anlamında olduğu; Türkçedeki "yazmak" fiilinin de "kazmak" fiiliyle sesteş ve anlamdaş olduğunu hatırlatalım) kullanıcısı olan belirgin tiplerin, içeriyle dışarının kesiştiği mekânlar olan pasajların müdavimi flâneurler gibi, kitle ile kendini perdeleyen ve bakıcı imiş gibi gezinip satıcı olan fenomenlere dönüştügünü söyleyebiliriz. İşbu simülatik flâneurler, orijinalleri gibi, sanat-hayat-ticaret konseptinin dişında, parodik-ideolojik-politik bir üçlemenin üreticisidirler. Baudrillard'ın simülasyon ve sanal bağlamında kullandığı ayartmaya ("kitlelerin medya tarafindan ayartıldığı bir evrende her şeyi olduğu konumdan başka bir konuma taşıyan güç..."), yazının/yazmanın ayartısı eklenince, çifte ayartılmış bir öznenin söylemindeki bencillik ve sapkınlık rahatça görülebilir hâle gelmektedir. $\mathrm{Bu}$ teknolojik ve psikolojik ayartıya, Âdem ve Havva kıssasında temsil edilen teolojik ve ontolojik ayartıyı ekleyecek olursak konu biraz daha sarahat kazanabilir: Hristiyan teolojisinde düşüşü, İslam ilahiyatında cennetten çıkarılışı anlatan mezkûr kıssada yasak meyve elmanın yenmesi sonucu insanlığın atasının/ anasının dünyaya düşüşü de (dünya, den olan, yani alçakta kalan, dolayısıyla bir nevi düşülen/ikincil yerdir) şeytani bir ayartmanın sonucudur. Şeytani ayartma ise kutsal metinlerin, bilhassa Kur'an'ın tabiriyle 'kötüyü, iyi/güzel/faydalı göstermek" türünden bir ayartıdır. ${ }^{24}$ Teknik' in lojik'le birleştirilmiş ve kutsanmış hâli

22 Bkz. John Berger, Görme Biçimleri, İstanbul, Metis Yayınları, 2019.

23 Martin Lings, Antik İnançlar ve Modern Hurafeler, İstanbul, İnsan Yayınları, 2016, s. 46.

24 Bkz. İdris Şengül, Kur'an Kıssaları Üzerine, Ankara, Işık Yayınevi, 1994. 
teknolojinin iyi/güzel/faydalı oluşuna dair kabul görmüş genel kanının ${ }^{25}$-ki araç olarak medya McLuhan'ın vurguladığı üzere insanın düşünsel ve sinirsel sisteminin uzantısıdır ${ }^{26}$ - dünyanın en gelişkin teknolojisine sahip bir firma tarafından hem isim hem amblem olarak kullanılması semiyotik olarak kayda değer bir detaydır. Isırılmış yarım elmanın gösterge-bilimsel anlamı, teolojik göndermesiyle birlikte okunduğunda modern insanın teknolojiyle nasıl ayartıldığını ifşa eder niteliktedir. Kısacası, simülatik flâneurler olarak Twitter kullanıcıları (fenomenler), fantazmagorik bir mekân olan sanal dünyada (sanal pasajlarda) parodik/politik/ ideolojik hesapların (sanal ikincil kimliklerin) arkasında ayartının (enformatik ve dezenformatik kışkırtmanın) dayanılmaz hafifliğiyle ücretli veya gönüllü biçimde "aylaklık" yapmaktadır.

\section{Twitter'ın Teknik Yapısı}

Radyo, televizyon ve sinema gibi neredeyse sadece üreticinin aktif olduğu klasik medya türlerini müteakip hem ideolojik hem teknolojik bazı değişimler sonucu tüketicinin/alımlayıcının üretim ve tüketim sürecine daha etkin katılarak daha aktif olabildiği, interaktif bir iletişimin olduğu ve böylece alımlayıcının medya merkezli konsantrasyonunun diri tutulduğu sosyal ağ, mikroblog vb. yeni medya türlerinin doğuşu McLuhan'ın "medya mesajdır" aksiyomunu geçerli kı1maktadır. Medya sadece bir mesaj üretim aracı değil, aynı zamanda tüketimi, hızı, hazzı, ikonayı, trendi, modayı, gerçeklikten kopuşu, kaçışı, konformizmi, voyeurism'i, militarizmi, ideolojiyi, kapitalizmi, kısacası algılama/düşünme/yaşama biçimlerini zerk eden bir mesajdır. Görsel algı türleriyle uyuşturulan zihinlerin derinlemesine düşünemeyecek hâle gelmesi, mesaj1 da bir tüketim nesnesi olarak hızlı (ve hazlı/eğlenceli) bir şekilde tüketmesini sağlayacak teknik ve dijital formlar geliştirmiştir. Modern zamanlarda insanların bir resital dinlemeye, uzun metinler okumaya, durağan filmler seyretmeye ne vakti vardır ne de yeterli zihin duruluğu. "Civıldayan" anlamına gelen Twitter'ın 280 karakterden (imlasından boşluğuna, görselinden emojisine kadar her şey bir karakterdir) oluşan metin mesajlarının paylaşıldığı, yeni nesil medya sistemleri arasında en popüler mikroblog olması hem kullanıcısına hizlıca mesaj üretme ve tüketme imkânı sunmasından hem de mesajın etkileşim gücünü (yanı hızlıca yayılma imkânını) sağlamasından kaynaklanmaktadır. 2006 yılında Jack Dorsey öncülüğünde 4 kişilik bir ekiple, Odeo isimli bir teknoloji firmasının pek ilgi çekmeyen podcasting uygulaması

25 Teknolojinin tek boyutlu insan yaratmasına dair eleştirisi için bkz. Jacquas Ellul, Teknoloji Toplumu, Bakış Kitaplı̆̆ı, 2003.

Bkz. McLuhan, Yaradanımız Medya, İstanbul, Nora Kitap, 2019. 
yerine "durum konsepti" olarak tasarlanan Twitter ${ }^{27}$ "ortak akıldan faydalanma ilkesi çerçevesinde kullanıcı katılımını en iyi uygulayan" sitelerden birisidir. ${ }^{28}$ Ekim 2020 itibarıyla 186 milyon aktif üyesi bulunan Twitter (aktif üye belirlemesi önemlidir, zira hesap açıp kullanmayan pasif katılımcılar olduğu gibi, sosyal ağ terminolojisiyle söyleyecek olursak "takipçi kasmak" amacıyla seri şekilde oluşturulan robotik [bot] hesaplar/üyeler de mevcuttur), politik simalardan yazarlara/düşünürlere, sanatçılardan sporculara, popüler kültürün ve popüler medyanın ürettiği fenomen tiplere kitlesel ilgi çekebilecek kişilerin platformu aktif olarak kullanmalarıyla popülerliğini günden güne artırmaktadır. 35 dilde aktif hizmet veren, haftada 185 milyon kere ziyaret edilen, günde 125 bin yeni katılımcı alan, günde 58 milyon tweet atılan sitenin temel özellikleri şunlardır:

- 280 karakterden oluşan metin mesajları oluşturarak tweet atmak. Mesaj metnine harfler dışında emojiler, görseller, fotoğraf, video, blog, web sitesi ve diğer kullanıcılar eklenebilir, etiketlenebilir.

- Gerek popüler/bilindik gerek tanıdık-tanımadık kullanıcıları takip (following) etmek onlar tarafindan takip edilmek ve böylece interaktif bir iletişim zemini oluşturmak.

- Başka bir kullanıcının girdiği metin mesajını/tweetini retweetleyerek ( $r t)$ metnin görünürlüğüne/yaygınlaşmasına katkıda bulunmak; favorilere ekleyerek ( $f a v$ ) popülerliğini artırmak[- metin mesajı isimlendirmesi yerleşik bir kalıp olduğu için kullanılmaktadır, yoksa söz konusu mesaj audio-visual-verbal bir mesajdır].

- Takip edilen veya edilmeyen herhangi bir kullanıcının metninin altına yanıt (mention) vererek açık/görünür iletişime geçmek ve interaktifliği artırmak.

- Takipleşilen kullanıcılarla özelden/gizli mesajlaşma [DM: Direct Message. Yakın zamanda getirilen bu özellik ile birlikte takipleşme şartı kaldırılmış, $D M$ kutusunun açık hâle getirilmesi kaydıyla herkesle özelden ve karakter sınırlaması olmadan mesajlaşma imkânı verilmiştir. Bu tür aplikasyonlar kullanıcı tepkilerini ve kullanım biçimlerine göre bazı özelliklerini güncelleyerek/yenileyerek kendilerini geliştirirler.]

- Hesabı kilitleyerek daha steril/spesifik bir alan oluşturmak veya sınırlamak/korunmak.

- İsten(mey)en kişilerin takibini engellemek (bloklamak).

27 Katrin Welner - Axell Bruns vd., Twitter ve Toplum, İstanbul, Kafka Yayınları, 2016, s. 13.

28 Ali Büyükaslan - Ali Murat Kınık, Gözlenen Toplumdan Gözetlenen Topluma: Sosyal Medya, İstanbul, Çizgi Kitabevi, 2016, s. 170. 
- Hakkında en çok tweet atılmış konuları (TT: Trend Topic) görmek, etiketli tweet atarak TT’nin oluşmasına nicel katkı sağlamak veya hashtag açarak yeni bir TT konusu belirlemeye çalışmak.

- $R t$ dışında tweet (gerek kendi gerek başkasının tweet'ini) alıntılamak.

- Dört seçenekli anket uygulamak.29

Bu teknik özelliklere sahip olan Twitter'ın en göze çarpıcı tarafı, kullanıcısını oldukça "aktif" kılmasına ve kendi popülaritesini sağlamasına imkân vererek platformun popülaritesini artırmaktır. Bu oldukça interaktif "hile", Twitter'ın yaygınlığını ve dolayısıyla da etkisini günden güne artırmaktadır. Kullanıcı attığ1 tweet sayısınca kendi takipçi sayısını artırma (dolayısıyla kendi etki alanını/ popülaritesini genişletme) imkânına kavuşurken aslında platformun yaygınlığın1, etkisini, gücünü, popülaritesini artırmaya hizmet etmektedir. Hangi amaçla (ister ekonomik, ister politik, ister ideolojik, ister parodik vb.) olursa olsun her kullanıcı kullandığı medya ile mesaj atarken medyanın bizzat kendisinin mesaja dönüşmesini; farklı bir alg1/düşünme/yaşama biçimi türünü inşa ettiğini; böylece aracın insanı biçimlendirmesini sağlamaktadır. Bu durum konumuz özelinde Twitter'ın yapısal özelliklerinden dolayı kurumsal popülaritesini (ve kuramsal politikasını) artırmaktadır. Kullanıcısını etkin olmaktan öte bizzat mesaj üreticisi olarak konumlandıran (söz söyleyen, espri yapan, haber veren, yorumlayan vb.) Twitter (bir Twitter kullanıcısının timeline denilen akışı-araya sitenin yerleştirdiği reklamlar dışında- tamamen takip edilen kullanıcı paylaşımlarından oluşmaktadır), kullanıcısını "kendisiyle aynı zaman ve mekânda bulunan bir topluluğun içinde duyumsatarak" ${ }^{30}$ bütün e-sosyal medyaların gerçeklik yanıltmacasını en etkili şekilde kullanan platformdur. Bunun temelinde ise "akış" (timeline) olgusu/ hissi vardır. Kullanımlar ve Doyumlar kuramına göre alımlayıcı medyayı ihtiyaç duyduğu bir alanda doyuma ulaşmak için kullanmaktadır. ${ }^{31}$

\section{Ontik Bir Dil/İmkân Olarak Twitter ve Semiyotik Açıdan Fenomenler veya Flâneurler}

A-sosyal modern insanı e-sosyal postmodern insan hâline dönüştüren yeni medya türleri arasında Twitter, Heidegger'den mülhem ifade edilecek olursa postmodernin evidir. Fantazmagorik bir olmaklığıla simülatik flâneurlerin gezindiği, kitle içinde kendilerini perdelediği ve kendilerine alıcı aradıkları pasaj veya siber uzam/siber pazar Twitter'ın, onun zamansiz ve zeminsiz evreninde

29 https://wearesocial.com/digital-2020 Erişim: 20 Kasım 2020.

30 Büyükaslan - Kınık, a.g.e., s. 175.

31 Bkz. John Fiske, İletişim Çalışmalarına Giriş, Ankara, Pharmakon Yayınları, 2013. 
barınan, kimlik inşa eden, varlık bulan, politik ve ideolojik söylem oluşturan modernlerin içinde anlam bulduğu/ürettiği post-existence bir alan olduğunu (özellikle Twitter'ın politik bir aygıt olarak kullanıldığı coğrafyalar için) rahatlıkla söyleyebiliriz. Bu post-existence alan içindeki yazınsal sözleri ve ikonik göstergeleri semantik, sentaktik ve semiyotik bir şekilde okuduğumuzu sansak da söz konusu sürecin/bağlamın bizim gerçeklik algımızı/dengemizi bozduğunu ve gerçekle bağımızı kopardığını, bir enformasyon zehirlenmesi yaşadığımızı iddia edebiliriz. Sosyal medya varlığımızı olmasa da varoluşumuzu sanallaştırarak bizi gerçek/lik düzleminden uzaklaştırmaktadır ve sanallığın asıl tehlikesi bedenlerin/nesnelerin yapaylaşması değil, dünyaya dair pratiklerin (dilin, düşüncenin, duyguların, ilişkilerin, "kim"liğin) yapaylaşmasındadır.

Ahmet Muhip'in mısralarını uyarlayacak olursak: "Sırf unutmak için, unutmak ey Twitter / Büyük yalnızlığını dünyanın" kabilinden sarıldığımız sosyal ağlar, sanal arkadaşl1klar kurarak da iletişimsel eylem ihtiyacını karşılayan bir mecra olarak durmaktadırlar. Takipleşerek (hâlbuki "eskiler iz sürerdi / biz muttasıl arıyoruz yeni insanlar") ikincil ve sanal kimliklerimizi/varlıklarımızı güncellememizi (tıpkı aplikasyonların güncellenmesi gibi) sağladığımız bu akışkan mecra, gerçekliği yutarak, bir "unutma hâli olan modernlik", hiper-gerçek ve post-gerçeklik içinde "hakikati unutmamızı, hakikati unuttuğumuz hakikatini de unutturarak" hakikatten kopmamızı sağlamaktadır ${ }^{32}$ : Her medya türü, politik doğasının uzantısı olarak gösterdiklerinden çok göstermedikleriyle, Bourdieu'nun ifadesiyle enformasyon bombardımanı altında gerekli asıl enformasyonu gizlemesiyle ${ }^{33}$ insanı toplumsal/siyasal gerçekten, oluşturduğu kültürel vasatla da insanı varoluşsal gerçekten uzaklaştırır. Epifanik değil ama katartik bir boşalma yaşadığımız (boşalma bedensel anlamda da ruhsal anlamda da bir tükenişi çağrıştırmaktadır ve insanın boşaldığ 1 kadar birik(tir)mesi gerekmektedir) sanal söylem platformu olan Twitter dijital bir prezervatiftir: Cümlelerin ve düşüncelerin (yani anlamın), zihnin rahmine (uterusa) doluşmasını ve dölleşmesini (yani anlamın insanın kendi içinde üremesini/çoğalmasını) engelleyen dijital bir zardır. Hızlı hızlı ve kısa kısa boşalmasını ve insanın içe(ride) birik(tir)mesini engelleyen dijital bir prezervatiftir.

Form olarak her ne kadar bir "yazı tarlası" gibi dursa da norm olarak söz takası/cakası/savaşı yapılan, 280 karakterlik yazı-kırması (karması) bir platform olan Twitter, yaşamayı bilmeyen modernin soluduğu ve saldığı karbondioksitle

32 Yusuf Kaplan, "Hakikatin İz'i', https://www.yenisafak.com/yazarlar/yusuf-kaplan/hakikatin-izi-55390, Erişim: 29 Nisan 2021.

33 Pierre Bourdieu, Televizyon Üzerine, Sel Yayınları, 2019. 
doldurduğu android bir hava sahası gibidir. Sermayeye ve siyasaya taalluk etmiş medya üreticilerinin pompaladığ sanal gündem ve oluşturduğu sanal aurada soluyan modern insan, soluduğu kirli havayı ortama tekrar tekrar salan ve bunu durmaksızın fotosentezleyerek sürdüren sentetik bitkilere dönüşmektedir. Söz konusu kirli hava akışı (timeline) Twitter'ın ontik (politik ve ideolojik) dilini de kuran temel unsurdur. Bu sanal suni teneffüs ile yitirilen her şeyden önce canlılık hissi/olgusu ve sonra canlılı̆ğn türevi olan diğer hassalar/hassasiyetlerdir. Fantazmagorik ve simülatik bir varoluş zemini olan Twitter (ve benzeri sosyal ağ yapılanmaları) varlığa, varlığını sorgulatacak/yoklatacak bir aralık bırakmamaktadırlar- bir varlık alanı/aralığı, mevcudiyetin oluşum gerekliliğidir; zira her şey bir "aralıkta" meydana/vücuda gelir; müziği ahenkli kılan ondaki sesler değil eslerdir. Sayısal/dijital alan, sinemadaki temel estetik öge olan "boşluklar" gibi boşluk kabul etmemektedir. Bir zincirin halkaları veya dijital hücre üremesi gibi arka arkaya kesintisiz biçimde sürmektedir. Kopukluk/boşluk/aralık sayısal sistemin iflası demektir. Akışın mutad biçimde ve ilanihaye sürmesi gerekmektedir. Boşluk diğer sayılarla/hücrelerle doldurulmaktadır. Fizik de (fiziksel hayat da) aritmetik de (dijital/sanal hayat da) boşluk kabul etmemektedir. Hâlbuki insanı Hölderlin'in deyişiyle "şairane mukim kılan" ve varoluşsal bir anlam bulmasını sağlayan tam da o boşluklardır. İnsan ancak Tanrısal ve varoluşsal boşluklarda vücut/ruh bulmaktadır.

Batı medeniyetinin göz, Doğu medeniyetinin söz merkezli olduğu iddia edilse $\mathrm{de}^{34}$ Batı düşüncesinin temelinde logos/söz vardır, bu sebeple onun kutsal metinleri “Önce söz vardı.” diye başlamaktadır. Batı uygarlığı logos/söz merkezlidir. Bu uygarlık "dil üzerinden ve dilin sınırları içinde gerçeği ele geçirmeye yönelir. Doğu medeniyeti ise, hakikati aktarmada dili ve dilin sınırlarını/kısıtlayıcılığını aşmaya çalışır." ${ }^{35} \mathrm{Bu}$ açıdan bakıldığında Twitter logo-centric/söz-merkezli düşünsel bir kültür aurasının bir türevi olarak yorumlanabilir. Bütün düşünsel, özellikle de felsefî ve teolojik, arka planı, mitolojik ve teolojik metinleri (ki Yeni Ahit aslında bir kitap değil kelamdır: İsa'nın sözleri/eylemleri üzerine yazılan "kanonik" metinlerden oluşmaktadır) anlamak (semantik) ve yorumlamak (hermenötik) üzerine kurulu olan klasik Batı düşüncesinin ekseninde bulunan "söz" ve "akı1" ${ }^{36}$, Aydınlanma ile birlikte rasyonalist ve materyalist bir dönüşüm geçirmiş, sözün transandental/aşkınsal tarafi (yani metafizik ve metaforik içeriği) Aristoteles, Kopernik, Descartes, Kant, Hegel, Saussure vb. çizgisinde seküler/dünyevî

34 Bkz. Dücane Cündioğlu, Sinema ve Felsefe, İstanbul, Kap1 Yayınları, 2017.

35 İsmail Süphandağı, Dil Şiir Hakikat: Doğu-Batı Arasında İslami Dil Arayışı, İstanbul, İz Yayınlar1, 2019, s. 34.

Bkz. Jacques Ellul, Sözün Düşüşü, İstanbul, Paradigma Yayınları, 2004. 
bir alana, yani fizik ve metonimik bir içeriğe hapsolmuştur. Artık söz (dolayısıyla ses), insanı göklere çıkarabilecek metafizik bir titreşim değil, yere çivileyecek, anlamı sabitleyecek fiziksel bir titreşimdir. Yazı bu bağlamda değerlendirildiğinde göksel olanı ve anlamı kancalayan profan bir karaktere sahiptir. Yazının bu profan karakterini, politik ve ideolojik anlamda işlevsel bir âlete dönüştüren yeni medya (Twitter), anlamın/olayın/güncelin/parodinin çivilendiği bir çarmıh/ zemindir. Yapısal olarak sinırlı sayıda harflerden (harf etimolojik olarak, "mızrak ucu", "k1lıcın keskin ucu" anlamlarına gelmekte, sivri bir uçla kazıma/yazma, dolayısıyla da tahrif ve tahrip etmedir ve Eski Yunanca karşılığı olan "grapho/ grafi" de aynı kök anlamlara sahiptir.) meydana gelen bir tweet'in felsefi temel unsurudur logos/söz. Bu bağlamda Twitter, politik gerçeğin, post gerçeğin, hiper-gerçeğin ve gerçeğin parodik hâlinin arz-1 endam ettiği, meta olarak sergilendiği (her metaın bir pahası ve alıcısı vardır) bir dijital fuar alanı, dijital aylakların gezindiği fantazmagorik bir pasajdır.

Bütün bu olguların ve olayların arkasında pek tabi robotik varlıklar değil, etten kemikten insanlar olduğu için hiçbir yargı kes(k)in olamaz fakat istiarenin amacı durumu daha sarih anlatabilmektir. Flâneur olarak nitelendirdiğimiz kullanıcılarının (fenomenlerin) barınağı ve sığınağı olan Twitter bir dijital bir döl yată̆ $\imath$ dır: Burada var olabilmenin birinci adımı merkezî bir sisteme kayıt/üye olup hesap açmakla (hesap vermekle), bunun karşıllğında da bir "profil" oluşturma imkânına (yani görsel ve sanal bir varoluş hakkını elde etme, bir kimlik inşa etme şansına) sahip olmaktır. Bir gerçek (ve tam görüntü) değil, sadece bir siluet olan profil ("profil” sözcüğü etimolojik olarak "çizmek" sözcüğünden gelmektedir), nominal tarafı oluşturulduktan sonra (yani isim ve kullanıcı bilgileri girildikten sonra) sıra gösteri toplumunun hafizasında yer bulabilmek, vücut kazanabilmek için görsel profil oluşturmaya gelir. Bu aşamada karşımıza çıkan semiyotik gösterge bir "yumurta" imgesidir. Dişinin çoğalma hücresini, üremeyi, varlık bulmayı temsil eden yumurta figürü, Twitter'daki hesabınızın (varlığınızın/kimliğinizin) ilk sureti, henüz biçimlenmemiş ilk surettir. Teknolojinin (aslında ideolojinin) kurmaca şekilde işler hâle getirdiği zihne boşalttığı dijital spermlerin döllediği "yumurta kafalar" artık biçimlenmeye hazır birer fetüs/cenin olarak görülebilir (son güncellemelerle yumurta figürü erkek-kadın silueti/figürü olarak değiştirilmiştir). Gösteri toplumunun bir üyesi olabilmek, varlık kazanabilmek, simülatik bir flâneur'e dönüşebilmek için yumurtanın hızlıca ikon/görsel ile et-kemik kazandığ 1 fetal evreye geçmesi gerekmektedir- elbette dileyen yumurta evresinde kalabilir ama Twitter dünyasında fenomen olmuş bir yumurta kafa göremezsiniz. Sanal hız ve sanal haz merkezli teknoloji evreninde 40 haftalık bir gebelik sürecine gerek olmaksızın hızlıca var olunabilmekte ve özdeşleşilen ikincil sanal kimliklerle söylenecek/eylenecek şeylerden haz alınmaya başlanabilmektedir. 
Kullanıldığı coğrafyanın sosyo-politik durumuna ve orada oluşturulmak istenen vaziyete göre farklı kullanım amaçları/biçimleri görebileceğimiz Twitter'ın en aktif ve işlevsel (ideolojik, politik ve parodik) olduğu yerlerden birisi Türkiye'dir. ${ }^{37}$ Birbirinden farklı birçok profilin var olduğu bu dijital platformun en temel karakterleri olan ve fenomen olarak isimlendirilen (Fransizca phénomène, Eski Yunancadan alınan ve "görünen şey" anlamında; epifani, fantezi gibi kelimelerle aynı kökten gelen; ve içeriğinde yine görsel bir taraf barındıran kelimedir ${ }^{38}$ ) kullanıcıların bazı karakteristik özelliklerinden bahsedecek olursak öncelikle bu kadar çok üyesi olan platformun kullanıcılarını sınıflandırmak ve tanımlamak oldukça güç ve bu makalenin amacının dışında kalan bir konudur. ${ }^{39}$ Bunun yerine fenomen kullanıcıların tipolojisine (edebiyat çalışmalarında "karakter" ve "tip" ayrımı yapılır ve karakter kendine has özellikleri olan kişilere, tip ise basmakalıp özelliklere sahip olan kişilere verilen addır) dair bazı tespitlerde bulunmak daha anlamlı görünmektedir.

Aynı şey olmamakla birlikte genel internet jargonunda zaman zaman "troll" olarak isimlendirilen fenomenlerin en genel özelliği pratik kullanıcılar/hesaplar olmalarıdır. Onlar güncele dair (politik, ideolojik, ekonomik, teolojik, poetik, artistik, popülist, sportif, medyatik) her şeyi capslerle, videolarla, karikatürlerle, sözlerle vb. tiye alan, gerçeği parodileştirip bir oyuna çeviren (parodi "taklide dayalı güldürü oyunu" anlamına gelmektedir), daha amiyane ama sarih bir ifadeyle her şeyi şakaya vuran/sarakaya alan ve gerçeğin/hayatın ciddiyetini bozma işlevi gören kişilerdir. Birçoğu bunu, mevzilendikleri ideolojinin açık ve gizli bir politik eylemi olarak yapmakta olup amaçları karşı ideolojinin ciddiyetinin, inandırıcılığının ve savunulabilirliğinin altını oymaktır. Fenomenlerin birçoğu, gerek gerçek hayattan (tarihten) gerekse kurmacadan (edebiyat ve sinemadan) antagonist veya absürt tiplerin görsellerini kendilerine profil fotoğrafi yapmaktadırlar. Örneğin; “@Cemil_Marki” kullanıcı adlı "Marki de Sekban” rumuzlu sol tandanslı troll'ün profil fotoğrafı olarak kullandığı görsel, Türk sinemasının sarhoş karakterlerinden birisi olan ve Sakar Şakir filminde Macit Flordun'un canlandırdığı "Marmara Kazım" tiplemesinin görselidir. Marmara Kazım Sakar Şakir

37 Wearesocial'ın 2021 yılı sosyal medya raporuna göre Türkiye, Twitter'ın en çok kullanıldığ 7. ülkedir. https://www.wearesocial.com/digital-2020 Erişim: 22 Nisan 2021.

38 https://www.nisanyansozluk.com/?k=fenomen Erişim: 20 Kasım 2020.

39 Wearesocial'in 2021 y1lı sosyal medya raporuna göre dünya genelinde aktif 353 milyon kullanıcısıyla en büyük (11.) sosyal ağ sitelerinden biri olan Twitter'ın Türkiye'deki aktif kullanıcı sayıs1 9 milyon civarındadır ve günde ortalama atılan 7 milyon tweet ile en çok kullanılan 5. sosyal medya platformudur. https://www.wearesocial.com/digital-2020 Erişim: 22 Nisan 2021. 
filminin antagonist (ikincil, zıt, rakip, düşman, muhalif, iş bozan) tiplemelerinden biridir. "Marki de Sekban" rumuzlu troll ise mevzilendiği ideolojik cephenin gönüllü veya pahalı lejyonerliğini kılıcıyla değil parodik işleyen zihninin ve dilinin kıvraklığıyla yaparak, karşıt/düşman ideolojinin milliyetçi-maneviyatçı eylemleriyle/söylemlerini doğrudan veya dolaylı olarak (bu yöntem daha zekicedir ve daha çok beğeni toplamaktadır) alaya alarak antagonist kimliğinin işlevini yerini getirmektedir. Sağ veya liberal tandanslı karşıt/farklı başka bir örnek ise: “@ Salieri_" kullanıcı adıyla boy gösteren fenomendir. Mozart döneminde saray müzisyeni olan ve haset derecesinde hayranlık duyduğu Mozart'a düşmanlık eden gerçek bir antagonist karakterin ismini kullanması ilgi çekicidir. Söz konusu fenomenlerin ifşasına yönelik bazı söylentiler ve bu kişilerden bazılarının yazar çizer tayfasından olduğuna yönelik iddialar, onları "pazarı görmeye çıktığını söyleyip aslında kendisine alıcı arayan flâneur" tipine biraz daha yaklaştırmaktadır.

Zikredilen fenomen/flâneur kullanıcılar, sıradan zamanlarda karşıt oldukları ideolojinin (hatta bazen taraf oldukları ideolojinin de) parodisini yaparak, sira dışı zamanlarda ise adeta havarilik veya lejyonerlik yaparak politik bir tavır takınmaktadırlar. Komik olduğu için popülere, sinsi olduğu için politiğe yakın olan bu antagonist karakterler trollıün kelime anlamı olan her türlü "rahatsızlık verme" eylemini (hayatın bütün ciddiyetini sarsacak, bütün değer yargılarını altüst edecek derecede genel bir rahatsızlık veriş söz konusudur) ve İskandinav mitolojisindeki "kötü cin" rolünü oynamayı görev bellemişlerdir. Fenomen/troll ve flâneur tipler arasında var saydığımız özdeşlik, literal değil her iki tiplemenin de "dijital aylak" olmaklığından ve parodik üslubuyla olayları sabote ederek gerçeklik düzlemlerinden koparmalarından kaynaklanan pratik bir ilişkidir.

Fenomen ya da trolllerin, antagonist karakterler ardina gizlenmeleri yahut o karakterlerle ikincil sanal kimlikler inşa ederek remaskülize olmaları, Twitter'ın hem teorik hem pratik (hem ontolojik hem epistemolojik) kurmaca yapısına dair bazı ipuçları sağlamaktadır. Protagonist (ana karakter) olarak konumlandırılmış medyanın kendisinin veya medyatik tiplerin (politikacı, sanatçı, sporcu, popüler tipler vb.) karşısında mevzilenen, o tiplerin zıttı olan antagonist trolllerin ikame edildiği kurmaca bir yer olan Twitter; medyatik ve gerçek (!) tiplerin ve olayların simülatik hiper-gerçek tipler tarafından tiye alındığ 1 bir ekran/sahne olarak iş görmesi; gerçekliğin her hâlükârda sanal tarafindan yutulduğu siber bataklık olan Twitter'ın aktif kullanımı, popülaritesi, yaygınlı̆̆ı, politik ve ideolojik işlevler görebilecek bir "medya/araç" oluşu, böyle bir amaçla kurulmamış olsa bile bu potansiyele sahip oluşu her medya gibi Twitter'ın da fictional politikaya angaje olmasını sağlamaktadır. Sulanması gereken bir kurmacayı gerçekliği sulandırarak yapan simülatik flâneurler Twitter'in teritoryasında siyasayı da piyasayı da 
işler hâlde tutmaktadır. Caligari'nin muayenehanesinden kaçarak fantazmagorik bir mekân olan Twitter'a sığınan trolllerimiz medya mesajının hem üreticisi hem tüketicisi olarak siber pazarı da ayakta tutmakta etkindirler.

Twitter'ın "genel kullanıcı" diyebileceğimiz, kurmacanın pasif ve nicel tarafını oluşturan kitlenin/kalabalığın politik ve simülatik varlığına dair ise şunlar ifade edilebilir: Tamamen alımlayıcı ve tüketici pozisyonunda olan takipçiler, genel olarak popülist bir tavırla medyatik (sevdikleri, ilgi duydukları, beğendikleri) kişileri takip etmektedir. Bu bir ideoloji salgını; sadece politik ideoloji değil, popülist ideoloji salgınıdır. Bazıları ise politik bir tavırla, düşman olduğu kesimin belirgin kullanıcılarını takip etmektedir. Kimi mention atarak savunmacı veya saldırgan bir tavir sergilerken, kimi sessiz ve tepkisiz bir takiple ahval-i umumiden haberdar olmak istemektedir. Genel eğilim, etkileşim içine girerek sanal bir söylem cedelleşmesine (genelde hakaret ve sövgü ile biten bir söz savaşına) girmek şeklinde belirmektedir. Zira Twitter'ın doğası (ve cazibesi) buna imkân vermekte ve âdeta takipçiyi buna kışkırtmaktadır. Kullanıcılar arasındaki inorganik ve uzak ilişki bir ayartı; teknolojik ve yakın iletişim ise bir imkândır. Bu iki aldatıc1 unsur, insanın insanî/organik bir dil kurması yerine, mekanik/medyatik bir çığırtkanlığa girişmesine sebep olmaktadır. Medyanın zaten yeterince klişeleşmiş ve ideolojik olan dili, Twitter'ın yazınsal zemininde kitcshvari bir şekilde yeniden üretilmektedir. İknacı olmaktan çok savunmacı, alaycı ve aşağılayıcı bir üsluba sahip olan tweet-politiğin dili, kişilerin "negatif katarsis" (nefret boşal1mı) yaşamasını sağlayarak, her modernin içinde var olan gizli medyatik canlının varlığına can katılmaktadır. Nefret boşalımı masumane bir tespit olarak kalabilir çünkü olayın toplumsal boyutu sosyolojik derin yarılmanın belirtisidir.

Genel olarak medyanın, konumuz özelinde Twitter'ın politik, ideolojik ve parodik dilinin kalıplaşmış algı ve söylem biçimleri, insanın bilinç altında (Pandora'nın kutusunda) kapalı duran "daimonik" (şeytani/kötücül) "ben"in (nefs/ self) gün yüzüne çıkmasına, etkileşiminin ayartısına kapılarak saldırgan, saygısız, alaycı ve düşmanca bir dil kullanmasına sebep olmakta ve kullanıcıları insani duyarlılıktan ve ortak bir dil kurmaktan uzaklaştırmaktadır. Birer modern olarak bu "mümbit" ve "fasit" dairenin/dilin diline dolanmaktayız ve dilimiz dolanmaktadır. Dilin canlı/sınırsız organik yapıs1, cansız/sınırsız mekanik bir yapıya evrilmektedir. Dil bir evse, dijital ağlarla örülmüş bir dil olarak medya dili evlerin en çürüğüdür. Bu durum iki taraflı bir etkileşimin sonucudur. Etkileşimin uçlarında insanın biçimlendirdiği medya/araç ve medyanın/aracın biçimlendirdiği insan vardır. Konu bütüncül olarak damarlardan çekilen hayati unsurlarla ilgilidir: Modernitenin somurduğu inanmak, yaşamak, umutlanmak gibi hayatı anlamlı kılan şeylerin yitimiyle ilgilidir. İnsan ve araç arasındaki etkileşimin zararı insani iliş- 
kilerin (iletişimin değil ilişkilerin; zira iletişim mekanik bir ilişki biçimidir) yok olmasına, insanın araçsallaşmasına sebep olmaktadır.

Kitle kültürünün ve kitle endüstrisinin gerçek hayatta meydana getirdiği yalnızlık ve güvensizlik hissini iliklerine kadar yaşayan modern insanın "zaman geçirmek için içerisine daldığı" fantazmagorik ve simülatik mekânlar oluşturmas1 (AVM'lerden Age of Empires, Candy Crush Saga tarz1 yer/toprak merkezli oyunlara kadar) ve insanları adeta bu sanal mekânlara hapsetmesi (insanların dış mekânın gerçek zemininde ontolojik bir güvensizlik duyumsaması; iç mekânın sanal zemininde epistemolojik bir güvenlik alanına mahkum etmesi) sadece teknoloji ile açıklanabilecek bir durum değildir. Ekonomik, politik ve ideolojik amaçlar/çıkarlar köklü bir paradigma dönüşümünün uzantısıdır ve oluşturmuş olduğu bu katastrofik durum seküler bir ağ yapılanmasının siyasa ve piyasa ile angaje olmuş (patronaj ilişkisi kurmuş) taallukunu; "toplumu gittikçe felakete yaklaştıran insanlık dışı bir kültür doğurduğu" ${ }^{40}$ gerçeğini ifşa etmektedir. Sadece bir illusion/görsel yanılsama değil, aynı zamanda bir zaman-mekân yanılsaması da oluşturan dijital teknolojinin ürünü olan e-sosyal medya, insanın, varoluşsal gerçek düzleminden koparılıp savrulmasına, dolayısıyla da gerçeklikten çok sanallığa (kurmacaya, oyuna vb.) tutunmasına yol açar.

Başat iki sosyal medyadan biri olan Facebook'un dijital zemininin duvar/ wall (duvar bir zemindir ve mekâna aittir) olarak isimlendirilmesi; bir diğeri olan Twitter'ın dijital zemininin zaman-çizgisi/zaman-akışı/timeline olarak isimlendirilmesi yukarıda bahsettiğimiz mekân-zaman yanılsamasını da desteklemektedir. Konumuz özelinde Twitter'ın bir sanal-zaman platformu, aldatıcı görüntüden çok aldatıcı akış olduğunu söyleyebiliriz. Gerçek zamanla senkronik bir şekilde ilerleyen/akan, ve gerçek hayatın içindeki akışı yine senkronik bir şekilde dijital görselin/işitselin/sözelin (yani sanalın) içine çeken, dolayısıyla kullanıcısını/al(ımlay)ıcısını da sanala mahkum eden bu ileri teknoloji bizleri elimizdeki araçlara göre gören, duyan, konuşan, gerçek dünyadan sanal dünyaya aktarmak için "enformasyon" toplayan bir medya-ajanı yapmaktadır. Virilio'nun deyişiyle, "gerçek zamanlı teknolojilerle gerçek varoluş yok olmaktadır". İnsanın eylem ve söylem alanını dijital olarak çoğaltan ama reel olarak daraltan e-sosyal ağlar insanı hayattan ("hayat" kelimesinin kökeninde yer alan "hayy" sözcügü "canlılık" anlamına gelmektedir) koparmaktadır. Bir şey öğrenmesi gerektiğinde kütüphaneye gitmek ve kitapları kurcalamak yerine veya bir hocanın tedrisinden geçmek yerine internet ve iletişim araçlarına sarılan; temel gıda maddesi saydığımız ekmeği bırakın

40 Akt. Nick Stevenson, Medya Kültürleri: Sosyal Teori ve Kitle İletişimi, İstanbul, Ütopya Yay1nevi, 2015, s. 327. 
yapmayı, almak istediğinde bile online sipariş verecek duruma gelen bir insanın/ toplumun canlılı̆̆ından söz etmek mümkün değildir. Burada politik ve ideolojik anlamda temel soru/n şudur: İnsanın gerçek hayattan koparılmasının, uzak tutulmasının, sanala mahkûm edilmesinin sebebi nedir? Emperyalizm ve kolonyalizm bağlamında cevap verilebilecek bu sorular bu makalenin sınırlarını aşmayı gerektirmektedir: Hayalî cemaatlerin yerini alan sanal cemaatlerden, insanların gerçeklik alanından çekilip boş bıraktığı dünya coğrafyasını sömüren medya emperyalizminden ve medya kolonyalizminden; "yeni yönetim mekanizmasının ulus-devlet değil küresel ekonomi olması[ndan]"41; Batı'nın medya aracılığıyla edilgin hâle getirdiği dünyayı istila edişinden bahsetmek için ayrı bir çalışma yapmak gerekecektir.

\section{Sonuç}

Bu makalede modern çağdaki paradigma dönüşümünün bir uzantısı/yansımaS1 olan medya pratiğinin sosyal medyayla birlikte modern insanı algısal ve düşünsel olarak içine çekmesine, değişen mekân algılarıyla birlikte değişen yaşamsal pratiklerin ve insanların (stereotiplerin) etkileşimine 1 şı tutmayı amaçladık. Modernitenin teknik ve rasyonalist devrimlerinin beraberinde getirdiği post-kapital düzen içinde kurulan modern yaşamın varoluşsal koşulları ve sorunları, modern bireyin bireysel ve toplumsal pratiklerini değiştirip dönüştürerek tarihteki örneklerinden çok farklı bir insan ve toplum tipi oluşturmuştur. Benjamin'in, modern yaşamın ve bireyin temsilcisi olarak gördüğü Baudelaire'in metinlerinden ve yaşamından hareketle ortaya koyduğu "fantazmagorik" mekân ve flâneur tipi ile analojik bir benzerlik kurduğumuz ve ilişkilendirdiğimiz postmodern simülatik uzam ve onun kullanıcısı olan postmodern birey Baudrillard'ın "artırılmış gerçeklik/aşırı gerçeklik" (hyper-réalité) olarak isimlendirdiği bir gerçeklik yanılsaması içerisinde "dijital aylak" gibi dolaşmakta; onun yaşama, varlığa, topluma karşı verdiği tepkiler kullan(11)dığı medyalar tarafından biçimlendirilerek politik ve ideolojik anlamda etkisizleştirilmektedir. Elektronik çağın ve dijital devrimlerin sonucunda kendi yaptığı devrimlerle girdiği etkileşim sonucunda dönüşüm geçiren bu postmodern birey profili, klasik bağlamda pasaj, modern bağlamda $A V M$, post-modern bağlamda siber uzam, yani yeni medya (sosyal medya) içinde kendisine yeni meskenler edinmiş, inter-aktif medyayı sanal aylaklık yaptığ 1 , kendisini pazara çıkardığı (pazarda sunduğu), tekno-modernliğin iletişimsel imkânlarını kullandığı mekân bellemiştir. Günümüzde, âdeta genişletilmiş bir şimdiki zaman içinde ikamet ettiği yer siber-uzam/medya olan dijitalleşmiş birey, politik ve ideolojik yapısı belirgin bir dijital varlık sahası olan Twitter'da simülatik 
kimliklerin arkasına saklanarak sanal varlığını oluşturmakta ve sürdürmektedir. Twitter, tekno-politik ve sosyo-kültürel kodlarıla, post-modern bireyin varoluşsal ihtiyaçlarını karşıladığı, kendi öz varlığını “-mış gibi” bir simülasyonun arkasına gizleyerek, parodik bir dil oluşturarak, enformatik ve ideolojik bir iletişimsel eylemde bulunduğu bir alan olarak belirmektedir. Bu alan/uzam, söz konusu iletişimsel eylemin bireyin biçimini, yapısını, içeriğini, amacını belirleyen ve dolayısıyla kullanıcıları "aldatıcı görünümler" içinde u/yutan dijital bir varlık alanıdır. Sonuç olarak, online girdiler ve çıtılarla yaşam döngüsüne katılmaya başlayan ve bu yeni "inter-aktif” bireyin yaşam motivasyonunu sağlayan sosyal medya, mekân, dil ve kimlik inşasında oldukça etkili bir işlev görmekte ve modern bireyin yaşamında kalıcı bir yer işgal etmektedir. 


\section{Kaynakça}

Aydoğan, Filiz (ed.), Yeni Medya Kuramları, Derin Yayınları, 2017.

Baudrillard, Jean, Simülakrlar ve Simülasyon, İstanbul, Doğu Batı Yayınları, 2003.

Benjamin, Walter, Pasajlar, İstanbul, Yapı Kredi Yayınları, 1993.

Berger, John, Görme Biçimleri, İstanbul, Metis Yayınları, 2019.

Bourdieu, Pierre, Televizyon Üzerine, İstanbul, Yapı Kredi Yayınları, 1997.

Büyükaslan, Ali - Kınık, Ali Murat, Gözlenen Toplumdan Gözetlenen Topluma: Sosyal Medya, İstanbul, Çizgi Kitabevi, 2016.

Castells, Manuel, Enformasyon Çă̆l: Ekonomi, Toplum ve Kültür: Ăg Toplumun Yükselişi-1, İstanbul, İstanbul Bilgi Üniversitesi Yayınları, 2013.

Cündioğlu, Dücane, Sinema ve Felsefe, İstanbul, Kapı Yayınları, 2017.

Dağ, Ahmet, Ölümcül Şiddet: Baudrillard'ın Düşüncesi, İstanbul, Külliyat Yayınlar1, 2011.

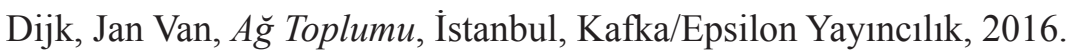

Dreyfus, Herbert, İnternet Üzerine, İstanbul, Küre Yayınları, 2016.

Ellul, Jacques, Sözün Düşüşü, İstanbul, Paradigma Yayınları, 2004. , Teknoloji Toplumu, İstanbul, Bakış Kitaplığı, 2003.

Fiske, John, İletişim Çalışmalarına Giriş, Ankara, Pharmakon Yayınları, 2013.

Kaplan, Yusuf, "Dijital Medya ve Özgürlük Problemi”, TRT Akademi, cilt 1, say1 1, 2016. lar/yusuf-kaplan/hakikatin-izi-55390, Erişim: 29 Nisan 2021.

Kırel, Serpil, Kültürel Çalışmalar ve Sinema, İstanbul, Kırmızı Kedi Yayınlar1, 2010.

Lings, Martin, Antik Inançlar ve Modern Hurafeler, İstanbul, İnsan Yayınları, 2016.

McLuhan, Marshal, Yaradanımız Medya, İstanbul, Nora Kitap, 2019.

Nişanyan Sözlük, "Fenomen”, https://www.nisanyansozluk.com/?k=fenomen, Erişim: 20 Kasım 2020.

Stevenson, Nick, Medya Kültürleri: Sosyal Teori ve Kitle İletişimi, İstanbul, Ütopya Yayınevi, 2015. 
Süphandağı, İsmail, Dil Şiir Hakikat: Doğu-Batı Arasında İslami Dil Arayışı, İstanbul, İz Yayınları, 2019.

Şengül, İdris, Kur'an Kıssaları Üzerine, Ankara, Işık Yayınevi, 1994.

Şentürk, Recep, İletişim ve Televizyon Teorileri, İstanbul, Küre Yayınları, 2017.

We Are Social, "Digital 2020", https://wearesocial.com/digital-2020, Erişim: 20 Kasim 2020.

Welner, Katrin - Bruns, Axell vd., Twitter ve Toplum, İstanbul, Kafka Yayınlar1, 2016.

Yavuz, Şahinde, Medya ve İzleyici: Bitmeyen Tartışma, Ankara, Vadi Yayınlar1, 2005. 